\title{
Investigation of apoptotic activities of NOE on human ovarian cancer cells
}

\author{
Mustafa ALBAYRAK *1, Hatice Mehtap KUTLU ${ }^{2}$ \\ ORCID: 0000-0003-2941-7574; 0000-0002-8816-1487
}

\author{
${ }^{1}$ Florence Nightingale Hospital, Department of Obstetrics and Gynecology, Istanbul, Turkey \\ ${ }^{2}$ Eskişehir Technical University, Faculty of Science, Department of Biology, Eskişehir, Turkey
}

\begin{abstract}
Ovarian cancer is one of the most malignan cancers of the reproductive system of women. Along with the other cancer types, ovarian cancer requires alternative agents for treatment due to the limited efficiency and strong side effects of classical chemotherapeutics and long treatment process. Recently, cancer investigations are focused on intracellular targets for cancer therapy. Sphingolipid molecules, especially ceramides of them are reported as potent targets for cancer therapy. Increased leves of ceramides into the cancer cells induce apoptosis and this increase can be caused by supressing ceramidases via new generation inhibitors of the enzymes. In this study, NOE (Oleoyl ethanolamide), a ceramidase inhibitor was used to cause cytotoxicity and induce apoptosis in human ovarian cancer cells, OVCAR-3. Our results clearly showed that NOE significantly reduced cell viability and caused cytotoxicity together with morphological changes indicating apoptosis that is proved with the flow cytometry results. NOE is proposed for a candicate for designing anti-cancer agent after further investigations.
\end{abstract}

Keywords: NOE, OVCAR-3, cytotoxicity

\section{İnsan yumurtalık kanseri hücrelerinde NOE'nin apoptotik etkilerinin araştırılması}

\section{Özet}

Yumurtalık kanseri, kadınların üreme sistemindeki en kötü huylu kanserlerden biridir. Diğer kanser türleri ile birlikte yumurtalık kanseri, klasik kemoterapötiklerin sınırlı etkinliği ve güçlü yan etkileri ve uzun tedavi süreci nedeniyle tedavi için alternatif ajanlara ihtiyaç duymaktadır. Son zamanlarda, kanser araştırmaları, kanser tedavisi için hücre içi hedeflere odaklanmaktadır. Sfingolipid molekülleri, özellikle seramidler, kanser tedavisi için güçlü hedefler olarak gösterilmektedir. Seramidlerin kanser hücrelerinde artan miktarları, apoptozu indüklemektedir ve bu artış, seramidazların yeni nesil enzim inhibitörleri yoluyla baskılanmasından kaynaklanabilmektedir. Bu çalışmada, insan yumurtalık kanseri hücreleri OVCAR-3'te sitotoksisiteye yol açmak ve apoptozu indüklemek için bir seramidaz inhibitörü olan NOE (Oleoyl ethanolamide)'i kullanmaktır. Sonuçlarımız, NOE'nin hücre canlılığını önemli ölçüde azalttığını ve akış sitometri sonuçları ile kanıtlanmış apoptozu gösteren morfolojik değişikliklerle birlikte sitotoksisiteye neden olduğunu açıkça göstermiştir. NOE, daha ileri araştırmalardan sonra anti-kanser ajanı tasarlanması için aday olarak tarafımızdan önerilmektedir.

\section{Anahtar kelimeler: NOE, OVCAR-3, sitotoksisite}

\section{Introduction}

Lipids have been reported to had role as a main structural component of cellular membranes. They have been involved in maintaining the structural and functional integrity of membranes. In recent years, it has been shown that the key biological role of lipids in the cells is cellular signalling as a member of secondary messengers in varying cellular

\footnotetext{
* Corresponding author / Haberleşmeden sorumlu yazar: Tel.: +905326871051; Fax.: +905326871051; E-mail: mustafaalbayrak@icloud.com

(C) Copyright 2021 by Biological Diversity and Conservation $\quad$ Received: 17.03.2021; Published: 15.04.2021
} 
processes such as cell proliferation and division. Lipids comprise of varying lipid classes of which sphingolipids are important both for membrane structure and cell signalling as secondary messengers in the cell. These molecules are named as the most significant lipid messengers. Biological activities of sphingolipids depends mainly on the length of carbon chain. Characteristics of the sphingolipid members are that they consist of 18-carbon atoms and are long-chain alcohol-based lipids containing sphingosine instead of glycerol. The membranous organel where sphingolipids are generated is endoplasmic reticulum. Due to the active roles in different biological processes in the cells as regulators in various cellular processes like growth, proliferation, stress response, differentiation and cell death (autophagy and apoptosis), sphingolipids are reported as potential targets in cancer research and therapy [1].

Ceramide, a sphingolipid member, is one of the main components of the cellular membrane and is involved in the protection of cell from stress signals and conditions [2]. It has been well documented for ceramide to induce apoptosis when its intracellular levels are increased based on various stimulants such as stress and toxic substances [3]. In addition, it is stated that the investigation of sphingolipid metabolism and the importance of ceramide are vital and promising in the treatment of complex diseases as cancer [3]. Intracellular ceramide levels can be decreased by a variety of enzymes that hydrolyze ceramide or convert it to sphingosine in turn direct cells to the survival and proliferation. Thus inhibitors of ceramidase enzymes are reported as main tumor supressing agents [3]. Oleoyl ethanolamide has been reported as of the first inhibitors of ceramidases that is an endogenous fatty acid ethanolamine and a lipid mediator [4,5]. Ceramidase inhibitors are known to induce apoptosis by causing ceramide accumulation [5-7].

Ovarian cancer is a frequent cancer type with high mortality and morbidity in women in the world [8-10]. The malignancy of this cancer type is mainly attributed to high metastatic capability [10]. Classical chemotherapy agents cause strong side effects that lead to difficulties and decrease the living quality of the patients [11]. Based on the data in this study it was aimed to investigate the cytotoxic, antiproliferative and apoptotic effects of N-Oleoyl ethanolamide (NOE) on human ovarian cancer cells OVCAR-3.

\section{Materials and methods}

\subsection{Materials}

Human ovarian cancer cell line (OVCAR-3) was obtained from the American Type Culture Collection (Manassas, USA). N-Oleoylethanolamide, MTT, fetal bovine serum (FBS), penicillin-streptomycin and RPMI-1640 were purchased from Sigma-Aldrich (St. Louis, USA), Annexin-V and Dead Cell Assay Kit was purchased from (Merck, Millipore, Hayward, California, USA).

\subsection{MTT assay}

Oleoylethanolamyde (NOE) was dissolved in DMSO to prepare a stock solution. $100 \mu \mathrm{M}$ and lower dilutions were obtained with complete RPMI-1640. NOE concentrations between 100-3,125 $\mu \mathrm{M}$ were applied to OVCAR-3 cells $\left(5 \times 10^{3} /\right.$ well $)$ in 96 well culture plate in triplicates. OVCAR-3 cells were incubated for 24 hours at $37^{\circ} \mathrm{C}$ and $5 \% \mathrm{CO}_{2}$ incubator. $20 \mu \mathrm{L}$ of MTT stock solution $(5 \mathrm{mg} / \mathrm{mL})$ was added per well and incubated again for 2 hours in the incubator. After the incubation liquids of the wells were changed with DMSO $(200 \mu \mathrm{L} /$ well) and read on an ELISA reader (HTX Synergy, BioTek, USA) at a wavelength of $570 \mathrm{~nm}(\mathrm{n}=3)$. Based on the obtained absorbances the viability percentages were calculated compared to control OVCAR-3 cells absorbance. The half maximal inhibition concentration (IC 50 ) of NOE on OVCAR-3 cells was detected from the obtained viability percentages and this value was used for further evaluations in this study [12].

\subsection{Confocal microscopy for morphological changes}

OVCAR-3 cells were plated on coverslips in a 6 well plate in triplicates to test the potent morphological changes of NOE. The plated cells were treated with the $\mathrm{IC}_{50}$ concentration of NOE for 24 hours under the same incubator conditions. Following the incubation OVCAR-3 cells were washed in PBS, fixed with glutaraldehyde and stained in phalloidin and acridine orange. All cell samples were imaged under a confocal microscope (Leica, TCS SP5 II, Germany) and evaluated for the morphological changes [13].

\subsection{Annexin-V staining}

Apoptosis trigering effect of NOE on OVCAR-3 cells was tested with annexin-V staining technique. For this manner OVCAR-3 cells were exposed to $\mathrm{IC}_{50}$ concentration of NOE for 24 hours in 6 well plates in cell culture incubator conditions. After the incubation period each cell group was added to separate tubes $(100 \mu \mathrm{L})$ and $100 \mu \mathrm{L} /$ tube of Annexin- $\mathrm{V}$ reagent was added. Test tubes were incubated for 15 minutes at room temperature in the dark. All samples were read on a Muse ${ }^{\mathrm{TM}}$ Cell Analyzer (Merck, Millipore, Hayward, California, USA) according to the instructions of the manufacturer of Muse ${ }^{\circledR}$ Annexin-V and Dead Cell Assay Kit [13]. 


\subsection{Statistical analysis}

The statistical analysis of the values were evaluated with one way Anova and Tukey post-test of Graphpad Prism 6.0. Obtained results were taken in consideration as statistically significant with the p value of $<0.05$.

\section{Results}

\subsection{MTT assay results}

The antiproliferative and cytotoxic activity of NOE on OVCAR-3 for 24 hours was detected via MTT colorimetric assay. The viability of OVCAR-3 cells was detected to be decreased by an increase in the applied NOE concentration. The highest decrease was detected after the applied the highest concentration of $100 \mu \mathrm{M}$ of NOE. Growth inhibition was statistically significant in applied doses of $100-6,25 \mu \mathrm{M}(\mathrm{p}<0.05)$. The lowest concentration of $\operatorname{NOE}(3,125 \mu \mathrm{M})$ was found to be slightly effective in decreasing the viability of OVCAR-3 cells in the exposure time of 24 hours but the decrease was not statistically significant (Figure 1).

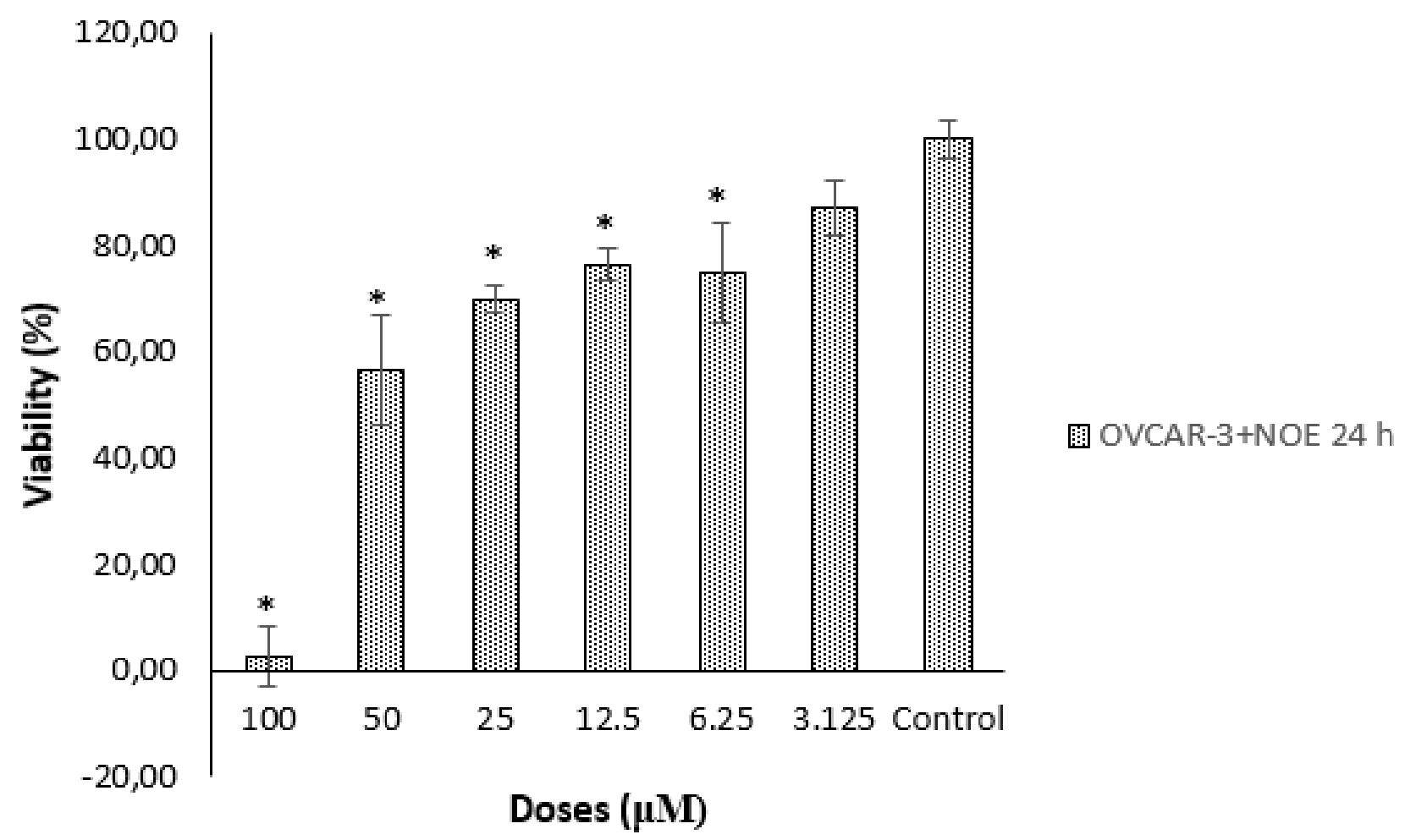

Figure 1. Growth inhibitory activity of NOE on OVCAR-3 cells for 24 hours. $\mathrm{IC}_{50}$ concentration of NOE on OVCAR-3 cells was detected as $56,07 \mu \mathrm{M}$ for 24 hours

\subsection{Confocal microscopic results}

Confocal microscopic evaluation was performed for detection of the morphological changes on OVCAR-3 cells caused by NOE. OVCAR-3 control cells were not treated with NOE and were found to be with compact and undamaged morphology. Whereas, OVCAR-3 test cells that were treated with the $\mathrm{IC}_{50}$ value of NOE for 24 hours were morphologically changed. The nuclei of OVCAR-3 cells exposed to NOE were shrank and with condensed chromatin. Holes on the cytoskeleton and fragmentations on nuclei were other changes detected in OVCAR-3 cells exposed to NOE (Figure 2). 

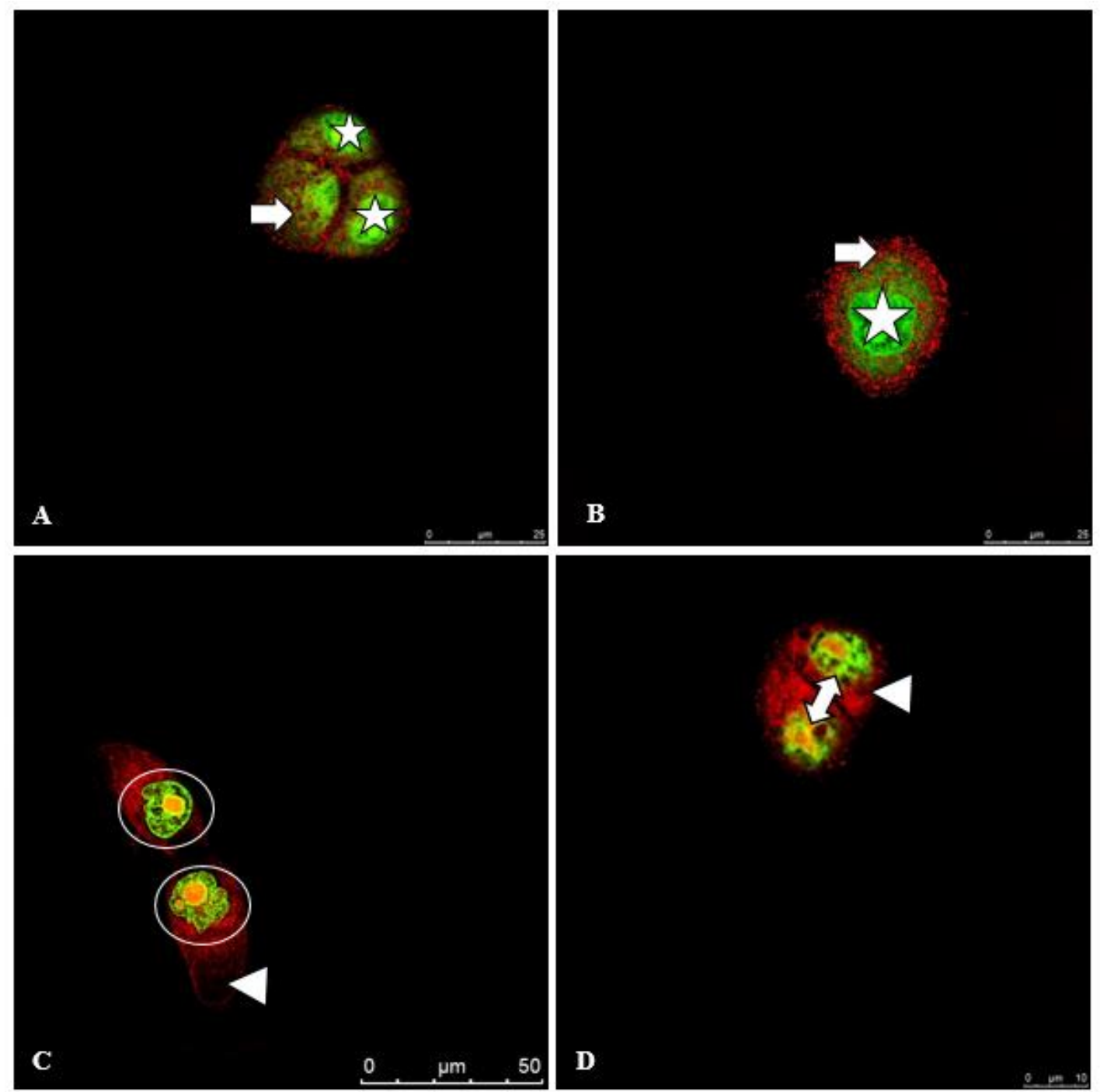

Figure 2. Confocal microscopic micrographs of OVCAR-3 cells stained with acridine orange and phalloidine. A, B. OVCAR-3 control cells: Asterisk-Nucleus, Arrow-Cytoskeleton. C, D. OVCAR-3 cells exposed to IC 50 dose of NOE for 24 hours: Arrowhead-Holes on cytoskeleton, Circle-condensed and shrank nucleus, Doubleheaded arrow-Fragmented nucleus

\subsection{Annexin-V findings}

Annexin-V staining results showed that treatment with NOE of human ovarian cancer cells for 24 hours trigered apoptosis. The viability of OVCAR-3 cells was found to be decreased to $76.10 \%$ in comparison with that of control OVCAR-3 cells that were with a viability percentage of 99.19. In control OVCAR-3 cells the total percentage of apoptotic cells was found to be approximately $1 \%$ whereas this percentage was detected as $23.65 \%$ after short-term cure with NOE. $21.11 \%$ of the total apoptotic cells in the profile of OVCAR-3 cells was found to be belong to early apoptotic stage and $2.54 \%$ were late apoptotic or death cells (Figure 3 ). 

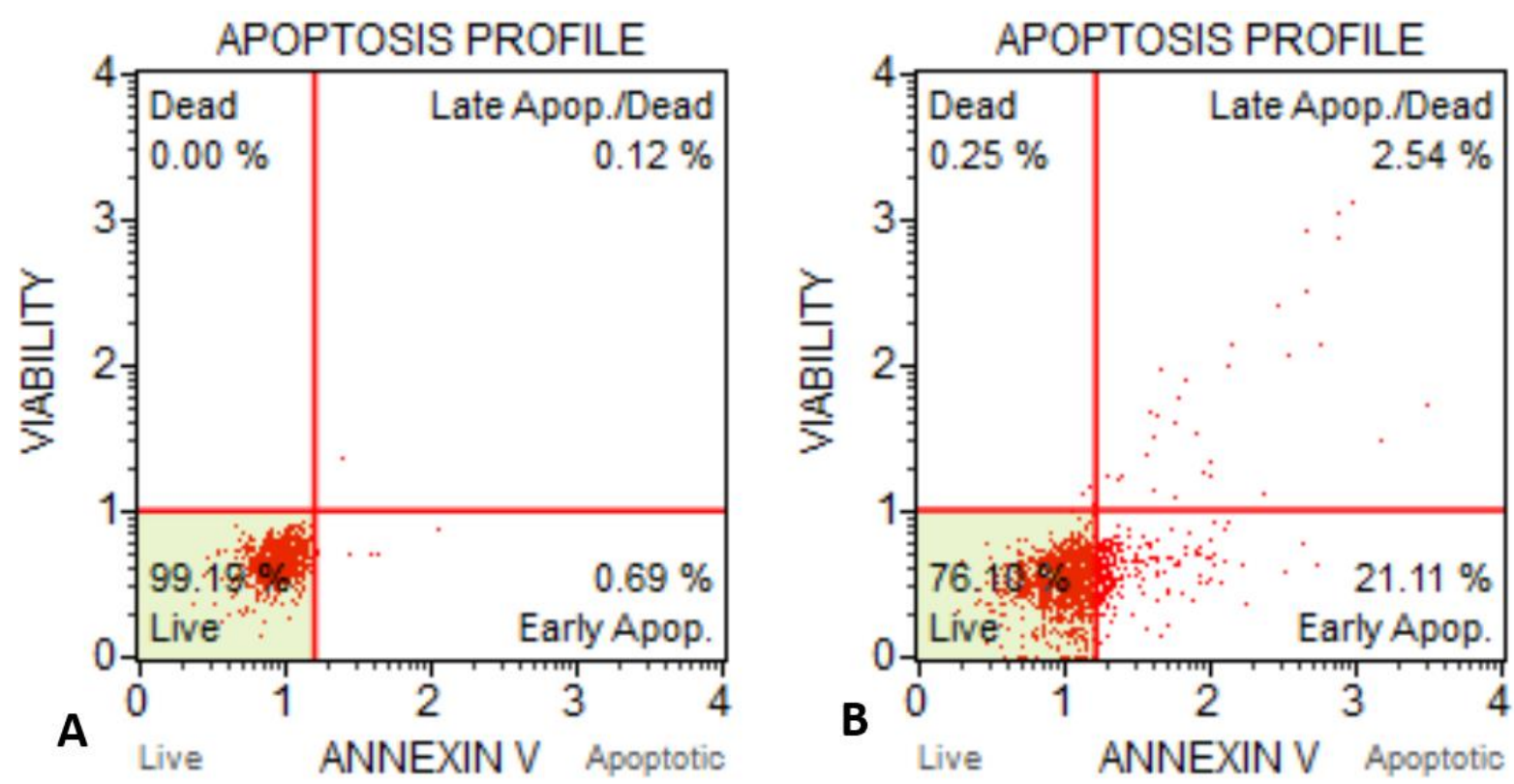

Figure 3. Annexin-V staining results of OVCAR-3 cells. A-Untreated OVCAR-3 cells (Live cells 99.19\%, Early apoptotic cells $0.69 \%$, Late apoptotic cells $0.12 \%$ ). B-OVCAR-3 cells treated with $\mathrm{IC}_{50}$ concentration of NOE for 24 hours (Live cells $76.10 \%$, Early apoptotic cells $21.11 \%$, Late apoptotic cells $2.54 \%$ )

\section{Conclusions and discussion}

Ovarian cancer belongs to the class of the most malignant cancers of the reproductive system of women. Recent studies on cancer aimed to find and use alternative agents for current chemotherapeutics and mainly focused on intracellular targets in signalling pathways as sphingolipid metabolism [14,15]. Herein, NOE was investigated as an inhibitor of ceramidase enzyme in the manner of cytotoxicity and proapoptotic activity on human ovarian cancer cells, OVCAR-3. MTT results indicated that NOE significantly inhibited the growth of OVCAR-3 cells in short-term application of 24 hours in concentration-dependent manner (Figure 1). This inhibition or antiproliferative activity may be attributted to the ceramide accumulation after treatment with the NOE that is a inhibitor of ceramidase enzyme. Researchers have reported that ceramide accumulation plays important roles in cancer cell proliferation and motility and that intracellular signalling pathways are proposed as a therapeutic target in ovarian cancer cells due to its frequent activity [8]. Another cancer researcher group have reported that cancer cells migrate and metastasize with compact actin cytoskeleton that means promote cancer progress [11]. Our confocal microscopy results (Figure 2) indicated that the morphology of OVCAR-3 cells is highly changed after treatment with NOE for 24 hours. The main changes were detected to be damages on cytoskeleton as holes and chromatin concensation and shrinkage of the nuclei. These changes were evaluated as apoptotic sparks as well as might be signs of disrupted migration and metastasis capacity of OVCAR-3 cells. Similar morphological changes were found by other researchers on human lung adenocarcinoma cells (A549) after the exposure to a ceramidase inhibitor (B13) [12]. Moreover, ceramide has been reported as an apoptosistrigering agent in cancer cells in its itracellular high levels [7]. Parallelly with this claim, in this study apoptosis was induced by the applied NOE on OVCAR-3 cells (Figure 3). The trigered cell death may be attributed to the increased intracellular ceramide levels due to the inhibition of ceramidases by applied NOE but the detailed mechanisms need to be uncovered.

As a conclusion in this study, it was showed that NOE as a ceramidase inhibitor supress cell growth, cause cytotoxicity and induce apoptosis in human ovarian cancer cells OVCAR-3 and is proposed for deeper evaluations as growth-suppressor agent in cancer cells..

\section{References}

[1] Gault, C. R., Obeid, L. M. \& Hannun, Y. A. (2010). An overview of sphingolipid metabolism: from synthesis to breakdown. Advances in Experimental Medicine and Biology, 688, 1-23.

[2] Mashhadi Akbar Boojar, M., Mashhadi Akbar Boojar, M. \& Golmohammad, S. (2018). Ceramide pathway: A novel approach to cancer chemotherapy. Egyptian Journal of Basic and Applied Sciences, 5, 237-244.

[3] Ogretmen, B. \& Hannun, Y. A. (2004). Biologically active sphingolipids in cancer pathogenesis and treatment. Nature Reviews Cancer, 4(8), 604-616. 
[4] Sugita, M., Williams, M., Dulaney, J. T. \& Moser, H. W. (1975). Ceramidase and ceramide synthesis in human kidney and cerebellum. Biochimicu et Biophysics Acta, 398, 125-131.

[5] López-Rodríguez, M., Viso, A., Ortega-Gutiérrez, S., Díaz-Laviada, I., López-Rodríguez, M. L., Viso, A. \& Díaz-Laviada, I. (2005). Involvement of cannabinoids in cellular proliferation. Mini-Reviews in Medicinal Chemistry, 5(1), 97-106.

[6] Liu, X., Cheng, J. C., Turner, L. S., Elojeimy, S., Beckham, T. H., Bielawska, A. \& Norris, J. S. (2009). Acid ceramidase upregulation in prostate cancer: role in tumor development and implications for therapy. Expert Opinion on Therapeutic Targets, 13(12), 1449-1458.

[7] Saied, E. M. \& Arenz, C. (2016). Inhibitors of ceramidases. Chemistry and Physics of Lipids journal, 197, 6068.

[8] Kitatani, K., Usui, T., Sriraman, S. K., Toyoshima, M., Ishibashi, M., Shigeta, S., Nagase, S., Sakamoto, M., Ogiso, H., Okazaki, T., Hannun, Y. A., Torchilin, V. P. \& Yaegashi, N. (2016). Ceramide limits phosphatidylinositol-3-kinase $\mathrm{C} 2 \beta$-controlled cell motility in ovarian cancer: potential of ceramide as a metastasis-suppressor lipid. Oncogene. 2801-2812.

[9] Lengyel, E. (2010). Ovarian cancer development and metastasis. Am. J. Pathol., 177,1053-1064.

[10] Banerjee, S. \& Kaye, S. B. (2013). New strategies in the treatment of ovarian cancer: current clinical perspectives and future potential. Clin. Cancer. Res., 19, 961-968.

[11] Yamazaki, D., Kurisu,. S. \& Takenawa, T. (2005). Regulation of cancer cell motility through actin reorganization. Cancer Sci., 96, 379-386.

[12] Çömlekçi, E., Kutlu, H. M. \& Vejselova Sezer, C. (2020). A new agent for the treatment of lung cancer: B13 loaded solid lipid nanoparticles. Advances in Natural Sciences: Nanoscience and Nanotechnology, 11 (4), 11 045014.

[13] Vejselova Sezer, C. (2021). Cytotoxic impacts of escin via inducing apoptosis and morphological changes on human prostate cancer cells. Biological Diversity and Conservation, 14 (1), 82-87.

[14] Kitatani, K., Idkowiak-Baldys, J. \& Hannun, Y. A. (2008). The sphingolipid salvage pathway in ceramide metabolism and signaling. Cell Signal., 20, 1010-1018.

[15] Ogretmen, B., Pettus, B. J., Rossi, M. J., Wood, R., Usta, J., Szulc, Z., Bielawska, A., Obeid, L. M. \& Hannun, Y. A. (2002). Biochemical mechanisms of the generation of endogenous long chain ceramide in response to exogenous short chain ceramide in the A549 human lung adenocarcinoma cell line. Role for endogenous ceramide in mediating the action of exogenous ceramide. J. Biol. Chem., 277, 12960-12969. 